\section{Candidatus Liberibacter asiaticus and Huanglongbing Effects on Citrus Seeds and Seedlings}

\author{
Ute Albrecht ${ }^{1}$ and Kim D. Bowman \\ U.S. Horticultural Research Laboratory, U.S. Department of Agriculture, \\ Agricultural Research Service, 2001 South Rock Road, Fort Pierce, FL \\ 34945
}

Additional index words. citrus greening, rootstock genotypes, sweet orange, seed quality, seedling growth, seed transmission

\begin{abstract}
Huanglongbing (HLB) is a devastating disease of citrus and threatens the citrus industry worldwide. The suspected causal agent of the disease is a phloem-limited bacterium of the genus Candidatus Liberibacter transmitted through insect vector or grafting with diseased budwood. Currently, most seed source trees for citrus rootstock propagation are located outdoors and unprotected from disease transmission. In addition, fruit from HLB-affected scion varieties in Florida containing seeds enter the commercial trade and move into other citrus-growing areas. The objective of this study was to determine how $\mathrm{Ca}$. L. asiaticus infection affects seed quality and seedling development and whether the disease appears in seedlings grown from infected fruit. Two experiments were conducted involving thousands of seedlings produced from seeds from infected rootstock seed source trees and 'Valencia' sweet orange trees, respectively. Infection of trees and fruit with $\mathrm{Ca}$. L. asiaticus significantly reduced seed weight, seed germination, and seedling height. Seedlings did not develop symptoms typical of HLB throughout the experiment. Polymerase chain reaction (PCR) analysis initially identified two of 686 rootstock seedlings and three of 431 sweet orange seedlings positive for the pathogen when they were very young. Resampling and PCR analysis of these five seedlings at older ages consistently indicated they were negative for the pathogen and none of these plants ever developed symptoms of HLB. It is suggested that $\mathrm{Ca}$. L. asiaticus may have been translocated into some part of the embryo during seed development but that it was not present in cells or tissue, which permitted replication or disease development as the seedling grew.
\end{abstract}

Huanglongbing (HLB), also known as "citrus greening," is a devastating disease of citrus, which is distributed in citrus-growing areas worldwide, ranging from Asia to the Indian subcontinent and neighboring islands to Saudi Arabia, Africa, and America (Bové, 2006). Although first reported in China in 1919, HLB was likely established in India much earlier (Gottwald et al., 2007). HLB was found in Florida in 2005 (Halbert, 2005), just 1 year after its first discovery in the Western Hemisphere in Brazil (Teixeira et al., 2005). Typical symptoms of the disease are an asymmetric blotchy mottling of leaves (McClean and Schwarz, 1970), often resem-

Received for publication 9 July 2009. Accepted for publication 16 Sept. 2009.

This research was supported in part by grants from the Florida Citrus Production Research Advisory Council.

Mention of a trademark, warranty, proprietary product, or vendor does not imply an approval to the exclusion of other products or vendors that also may be suitable.

We thank Lindsey Turnbull and Kerry-Shea Worton for excellent technical assistance and Ric Stange for suggestions and critical review of the manuscript.

${ }^{1}$ To whom reprint requests should be addressed; e-mail ute.albrecht@ars.usda.gov. bling zinc-deficiency symptoms, which leads to the typical appearance of yellow shoots in the tree canopy. Fruit produced on infected trees are often small or misshapen, do not color properly, and often contain aborted seeds. Later stages of the disease lead to fruit drop and twig dieback, rendering a tree nonproductive within 2 to 3 years, thus generating substantial economic losses to the citrus industry in affected areas.

The suspected causal agent of HLB is a fastidious, phloem-limited, Gram-negative bacterium (Garnier et al., 1984), which has not been obtained in pure culture until recently (Sechler et al., 2009). Three Candidatus spp. of the pathogen are currently known. The most widespread Asian species, $\mathrm{Ca}$. Liberibacter asiaticus, is found in all HLBaffected countries except Africa. The African species, $\mathrm{Ca}$. L. africanus, and the American species, $\mathrm{Ca}$. L. americanus, are so far restricted to Africa and Brazil, respectively (Garnier et al., 2000; Teixeira et al., 2005). Transmission of the bacteria occurs through insect vector, but while $C a$. L. asiaticus and $\mathrm{Ca}$. L. americanus are transmitted through Diaphorina citri Kuwayama, the Asian citrus psyllid, Ca. L. africanus, is transmitted through the African citrus psyllid, Trioza erytrea Del Guercio. In addition, transmission can occur by dodder (Cuscuta sp.) and through grafting with diseased budwood (Halbert and Manjunath, 2004). A recent study reported on the association of a phytoplasma with disease symptoms typical for HLB in citrus-growing areas in São Paulo State, Brazil (Teixeira et al., 2008). Presently, it is not known which vector is involved in the transmission of this pathogen.

HLB affects all known citrus species and citrus relatives with little known resistance and no known cure. Major management strategies are insecticide applications to reduce psyllid populations, removal of infected trees to eliminate sources of bacterial inoculum, and the establishment of pathogenfree nursery systems. Although extensive efforts have been made to establish screenprotected sources of budwood for nursery propagations, currently most of the seed source trees for rootstock propagation are unprotected outdoors. There is also concern that seeds from infected scion varieties in Florida transported through fresh fruit commerce may introduce HLB into countries or areas not yet affected by the disease.

Little information exists on whether $C a$. Liberibacter $\mathrm{sp}$. is transmissible by seed. Tirtawidjaja (1981) reported on the occurrence of stunted chlorotic seedlings with mottled leaf symptoms derived from fruit affected by citrus vein degeneration regarded as synonymous to HLB, suggesting the possibility of seed transmission of the pathogen. Graham et al. (2008) observed a small percentage of seedlings positive for $\mathrm{Ca}$. L. asiaticus grown from seeds of HLB-affected citrus trees using quantitative polymerase chain reaction (PCR) analysis. The pathogen was also detected in citrus seedlings from seeds of symptomatic fruit from several citrus varieties, although detection of the bacterium by PCR did not correlate with the appearance of disease symptoms (Hartung et al., 2008).

Transmission of diseases by seed has been demonstrated for various bacteria such as Xanthomonas axonopodis pv. phaseoli in bean (Darrasse et al., 2007) and Acidovorax avenae ssp. citrulli in watermelon (Walcott et al., 2003), and different infection pathways for seedborne pathogens have been described. Seeds may become contaminated externally by flower and fruit as a result of contact with bacterial populations on symptomatic tissue (Kaufman and Leben, 1974) or through internal infection by stylar tissues (Walcott et al., 2003). In addition, internal contamination of the seed can occur by systemic movement of the pathogen through the vascular system (Agarwal and Sinclair, 1987; Aggour et al., 1989). Studies on the distribution of $\mathrm{Ca}$. L. asiaticus in different citrus tissue demonstrated the presence of the pathogen in seedcoats and other parts of fruit from infected trees as well as in different parts of the flowers (Tatineni et al., 2008). However, the systemic transmission of liberibacters from fruiting tree, to seeds, to developing seedlings remains to be determined.

The main objectives of this study were to investigate the effects of $\mathrm{Ca}$. L. asiaticus infection on seed quality and seedling 
development and whether seedlings grown from affected fruit develop HLB disease. Two experiments were conducted using either seeds from rootstock source trees of six different genotypes or seeds from 'Valencia' sweet orange trees, and seed number, seed weight, germination rate, and seedling height were determined. Seedlings produced from seeds of infected fruit were analyzed by PCR for the presence of $\mathrm{Ca}$. L. asiaticus and evaluated for health and the development of disease symptoms typical for HLB.

\section{Materials and Methods}

\section{Plant material}

Rootstock genotypes. Trees symptomatic for HLB and PCR-positive for Ca. L. asiaticus were identified at the USHRL-USDA Farm in Fort Pierce (St. Lucie County, FL). Seed source trees of six different rootstock genotypes, Citrus macrophylla Wester, Vangasay lemon (C. vangasay Bojer), US-802 [C. grandis (L.) Osbeck $\times$ Poncirus trifoliata L. Raf.], Cleopatra mandarin (C. reticulata Blanco), Sun Chu Sha (C. reticulata Blanco), and sour orange $(C$. aurantium L.), were chosen for the experiment. In addition, trees not symptomatic for HLB and PCR-negative for $C a$. L. asiaticus were selected for $C$. macrophylla, US-802, Sun Chu Sha, and sour orange from the same location. Source trees from all six genotypes were also selected from the Whitmore Foundation Farm near Leesburg (Lake County, FL), located $260 \mathrm{~km}$ northwest of Fort Pierce, which was not found to be affected by HLB at the time of the experiment. PCR analysis confirmed the absence of the bacterium in these trees at the Whitmore Farm. One tree was chosen from each genotype and treatment except for US802, of which four PCR-positive trees were chosen. Trees at Fort Pierce were 3 to 8 years old, whereas trees at the Whitmore Farm were 18 to 21 years old.

'Valencia' sweet orange. For the second experiment, 28 8-year-old trees with 'Valencia' [C. sinensis (L.) Osb.] scion, symptomatic for HLB and PCR-positive for $C a$. L. asiaticus, were identified at the USHRL Farm in Fort Pierce. In addition, 10 'Valencia' trees of the same age not symptomatic for HLB and PCR-negative for the bacterium were selected from the same location.

\section{Collection of fruit}

Fruit from all rootstock genotypes were collected in Oct. 2007. PCR-positive trees had noticeable leaf symptoms for HLB disease, whereas PCR-negative trees did not. Unlike sweet orange trees, which typically have pronounced fruit symptoms when they are $\mathrm{Ca}$. L. asiaticus-positive, none of the fruit from the rootstock genotypes that displayed leaf symptoms were observed to display the fruit symptoms generally associated with HLB. The number of fruit obtained from all genotypes is depicted in Table 1. Peduncles were collected for PCR analysis.

Fruit from 'Valencia' scions were harvested in Apr. 2008. Fruit of predominantly

Table 1. Number of fruit and seeds collected from rootstock seed source trees located at the USHRL Farm in Fort Pierce and at the Whitmore Foundation Farm near Leesburg.

\begin{tabular}{|c|c|c|c|c|}
\hline Genotype & Location & Source tree ${ }^{z}$ & $\begin{array}{l}\text { Number } \\
\text { of fruit }\end{array}$ & $\begin{array}{c}\text { Total number } \\
\text { of seeds }\end{array}$ \\
\hline \multirow{3}{*}{ C. macrophylla } & Fort Pierce & PCR-positive & 48 & 1,374 \\
\hline & Fort Pierce & PCR-negative & 20 & 641 \\
\hline & Whitmore & PCR-negative & 10 & 490 \\
\hline \multirow[t]{2}{*}{ Vangasay lemon } & Fort Pierce & PCR-positive & 49 & 952 \\
\hline & Whitmore & PCR-negative & 10 & 490 \\
\hline \multirow[t]{3}{*}{ US-802 } & Fort Pierce & PCR-positive & 56 & 2,385 \\
\hline & Fort Pierce & PCR-negative & 9 & 383 \\
\hline & Whitmore & PCR-negative & 25 & 971 \\
\hline \multirow[t]{2}{*}{ Cleopatra mandarin } & Fort Pierce & PCR-positive & 100 & 1,790 \\
\hline & Whitmore & PCR-negative & 10 & 490 \\
\hline \multirow[t]{3}{*}{ Sun Chu Sha } & Fort Pierce & PCR-positive & 101 & 1,038 \\
\hline & Fort Pierce & PCR-negative & 25 & 248 \\
\hline & Whitmore & PCR-negative & 10 & 490 \\
\hline \multirow[t]{2}{*}{ Sour orange } & Fort Pierce & PCR-positive & 70 & 1,114 \\
\hline & Whitmore & PCR-negative & 25 & 941 \\
\hline Total & & & 568 & 13,797 \\
\hline
\end{tabular}

${ }^{\text {z }}$ Source trees were identified as positive or negative for $\mathrm{Ca}$. L. asiaticus by PCR analysis of leaf midribs and petioles.

$\mathrm{PCR}=$ polymerase chain reaction .

green color and irregular shape, typical of HLB disease, were collected from 28 trees positive for $\mathrm{Ca}$. L. asiaticus. Fruit of mature coloration and regular shape were collected from 10 trees negative for the bacterium. One or more sets of 12 fruit were obtained from each tree, resulting in a total of 36 fruit samples from PCR-positive trees and 10 samples from PCR-negative trees. Peduncles were collected for PCR analysis.

\section{Seed extraction}

Fruit were disinfected for 10 min with $1 \%$ (v/v) sodium hypochlorite (Clorox Co., Oakland, CA) containing $0.01 \%(\mathrm{v} / \mathrm{v})$ Tween 20 (Sigma-Aldrich, St. Louis, MO) and rinsed with water. Seeds were extracted and soaked overnight in water containing $0.15 \mathrm{U} / \mathrm{mL}$ pectinase (Sigma-Aldrich). Seeds were then rinsed with water, incubated in $1 \%(\mathrm{w} / \mathrm{v}) 8^{8}$ quinolinol hemisulfate salt (Sigma-Aldrich) for $30 \mathrm{~min}$, dried, weighed, and stored at $4{ }^{\circ} \mathrm{C}$.

\section{Growth and maintenance of seedlings in the greenhouse}

Rootstock genotypes. Seeds were sown individually in $3.8 \mathrm{~cm} \times 21-\mathrm{cm}$ Ray Leach "Cone-tainers" (SC10 Super Cell; Stuewe \& Sons, Corvallis, OR) containing steamsterilized potting medium composed of peat/ perlite/vermiculite (Pro-Mix BX; Premier Horticulture Inc., Red Hill, PA) in Dec. 2007 and irrigated as needed. A total of 13,797 seeds were sown, of which 8,653 originated from trees positive for $\mathrm{Ca}$. L. asiaticus (Table 1). Seedlings were grown under natural light conditions in the greenhouse at an average weekly temperature of 23 to $28^{\circ} \mathrm{C}$ and fertilized weekly by addition of a water-soluble fertilizer mix, $20 \mathrm{~N}-10 \mathrm{P}-20 \mathrm{~K}$ (Peters Professional; The Scotts Company, Marysville, $\mathrm{OH})$. Groups of plants from each fruit were arranged randomly on the greenhouse benches within each genotype. To examine the effect of increased stress on disease development, fertilization was stopped 5 months after sowing after the assessment of seed germination. Seedling size was determined from a random subset of seedlings 6 months after sowing.

'Valencia' sweet orange. Individual seeds were sown as described for rootstock genotypes in June 2008. A total of 1743 seeds were sown, of which 1256 originated from fruit affected by HLB. Seedlings were grown under natural light conditions in the greenhouse at an average temperature of 26 to $28^{\circ} \mathrm{C}$ and were fertilized weekly as described previously. Groups of plants from each fruit were arranged randomly on the greenhouse benches. Germination rate and seedling size were determined 7 weeks after sowing.

\section{Collection of tissue for polymerase chain reaction analysis}

For PCR analysis of field-grown trees, petioles and midribs from six symptomatic leaves were collected per tree. Fruit peduncles were collected individually from US-802, sour orange, C. macrophylla, and Vangasay lemon. As a result of their small size, peduncles from Sun Chu Sha and Cleopatra mandarin were pooled into groups of four. Peduncles from 'Valencia' oranges were combined for each set of 12 fruit and analyzed collectively.

For PCR analysis of greenhouse-grown rootstock seedlings, petioles and midribs from six leaves were collected from a subset of 338 seedlings at 4 to 5 months after sowing. PCR analysis was repeated 2 months later with a different subset of 348 seedlings. Only seedlings from fruit or groups of fruit exhibiting the strongest PCR signals for $\mathrm{Ca}$. $\mathrm{L}$. asiaticus after peduncle analysis were selected for tissue collection. The number of seedlings analyzed for each genotype is shown in Table 2. Seedlings that tested positive for $C a$. L. asiaticus were reanalyzed at 7, 9, and 15 months after sowing.

To ensure the detection of a possibly transient presence of $\mathrm{Ca}$. L. asiaticus in the plant tissue, PCR analysis of greenhousegrown 'Valencia' seedlings was performed soon after germination. The first pair of leaves emerging above soil level was collected from 
each seedling 7 to 10 weeks after sowing when seedlings reached a minimum height of 4 to $5 \mathrm{~cm}$ and leaves could be removed with minimal impact to the plant. Leaf samples were collected from 12 seedlings per fruit set where possible, resulting in a total of 431 samples. Seedlings from all fruit sets were included in the analysis. Seedlings that tested positive for $C a$. L. asiaticus were reanalyzed 4 weeks and 9 months after the initial analysis. This time petioles and midribs were collected for PCR detection.

Ten weeks after sowing, some of the 'Valencia' seedlings from noninfected and infected fruit developed a chlorosis resembling iron-deficiency symptoms. Leaf tissue from 91 of these chlorosis-affected seedlings derived from infected fruit was collected and subjected to PCR analysis. Deficiency symptoms were remediated within 2 weeks through a soil application of chelated iron (Sequestrene 138; Becker Underwood Inc., Ames, IA) at a rate of $1 \mathrm{~g} \cdot \mathrm{L}^{-1}$ and reduced watering.

Plant tissue was stored at $-20{ }^{\circ} \mathrm{C}$ until PCR analysis.

\section{Polymerase chain reaction detection of Ca. $\mathrm{L}$. asiaticus}

Leaf tissue was ground in liquid nitrogen with a mortar and pestle. One hundred milligrams of ground tissue was used for DNA extraction. DNA was extracted using the Plant DNeasy Mini Kit (Qiagen, Valencia, CA) according to the manufacturer's instructions. To monitor the possibility of contamination during the extraction process, DNA controls were prepared from leaves of Mangifera indica (mango), a nonhost of $\mathrm{Ca}$. L. asiaticus, at a rate of one control per 25 citrus samples. PCR amplifications were performed in singlestep reactions using primers $\mathrm{F} 1$ (5'-TGAA TTCTTCGAGGTTGGTGAGC-3') and R1 (5'-AGAATTCGACTTAATCCCCACCT-3') as described by Ding et al. (2005). Reactions were performed in closed $0.2-\mathrm{mL}$ PCR tubes (eight-tube strips; USA Scientific, Ocala, FL) in a total volume of $12.5 \mu \mathrm{L}$ using the Platinum SuperMix (Invitrogen, Carlsbad, CA). Each reaction included 1 to $2 \mu \mathrm{L}$ of DNA template, equivalent to 20 to $30 \mathrm{ng}$ of total DNA, and $0.5 \mu \mathrm{L}$ of each primer at a final concentration of $0.5 \mu \mathrm{mol}$ each. Amplifications were carried out in duplicate in a PTC-100 or PTC-200 Thermal Cycler (MJ Research, Reno, NV). PCR products were separated by electrophoresis in $2 \%$ agarose gels (Amresco, Solon, $\mathrm{OH}$ ) for $70 \mathrm{~min}$ at 5 to $6 \mathrm{~V} \cdot \mathrm{cm}^{-1}$, stained with ethidium bromide, and visualized under ultraviolet light (Fluor S Imaging System; Bio-Rad Laboratories, Hercules, CA). A comparison with quantitative real-time PCR using primers developed by $\mathrm{Li}$ et al. (2006) showed that amplification products generated with primers F1 and F2 are detectable well within the range of $\mathrm{Ct}$ values considered diagnostic for HLB.

\section{Statistical analyses}

Analysis of variance (ANOVA) was conducted to determine the effect of $\mathrm{Ca}$. L. asiaticus infection on seed number, seed weight, seed germination, and seedling size.
Significant $(P<0.05)$ ANOVA tests were followed by multiple comparisons of means using Tukey's honestly significant difference procedure. All analyses were performed using STATISTICA Version 6.0 (StatSoft, Tulsa, OK).

\section{Results}

Effect of Ca. L. asiaticus on rootstock seed quality and seedling growth. PCR analysis of peduncles from a total of 424 fruit collected from infected field trees identified 219 fruit positive for $\mathrm{Ca}$. L. asiaticus (Table 3 ). Of the 8653 seeds from infected trees, a total of 7254 produced viable seedlings with 3557 derived from fruit with peduncles positive for the bacterium.

The average number of seeds per fruit ranged from 10 seeds for Sun Chu Sha to 45 seeds for US-802 and did not differ significantly between infected and noninfected fruit in five of the six genotypes studied (Table 4). However, the number of seeds in sour orange fruit from the Whitmore Foundation Farm exceeded $37(P=0.0001)$, which is more than double the number of seeds per fruit collected from infected and noninfected trees of the same cultivar at the Fort Pierce location.

Seed weights ranged from $85 \mathrm{mg}$ for seeds from Vangasay lemon to $266 \mathrm{mg}$ for seeds from US-802 (Table 4). Infection significantly $(P=0.014)$ reduced the weight of seeds from C. macrophylla from $130 \mathrm{mg}$ for healthy control trees to $96 \mathrm{mg}$ for seed from infected fruit from the Fort Pierce location. A similar effect $(P=0.006)$ was observed for seeds from Sun Chu Sha, which weighed $98 \mathrm{mg}$ when produced in infected fruit compared with $108 \mathrm{mg}$ to $112 \mathrm{mg}$ when produced in noninfected fruit. Seeds from both PCRpositive and -negative sour orange fruit from infected trees at Fort Pierce weighed significantly $(P=0.004)$ less compared with seeds from the Whitmore Farm.

Percentage of germination was significantly affected by $C a$. L asiaticus in seeds from Sun Chu Sha $(P=0.003)$ and sour orange $(P=0.047)$, which had germination reduced from $96 \%$ to $86 \%$ and $76 \%$ to $62 \%$, respectively (Table 4). It could not be clearly determined whether significant differences between germination for seeds from the Fort Pierce Farm and the Whitmore Farm for the cultivars $C$. macrophylla, Vangasay lemon, and Cleopatra mandarin were related to infection by $\mathrm{Ca}$. L. asiaticus or other environmental effects.

The average number of seedlings per seed ranged from 1.1 in sour orange to 1.8 in $C$. macrophylla and was not significantly affected by the bacterium.

More than 13,000 seedlings were produced from seeds from all fruit sources, and a random subset of 3,812 seedlings was analyzed to evaluate the effect of $\mathrm{Ca}$. L. asiaticus on

Table 2. Number of rootstock seedlings analyzed by PCR for the presence of $\mathrm{Ca}$. L. asiaticus.

\begin{tabular}{|c|c|c|c|c|c|c|}
\hline \multirow[b]{2}{*}{ Genotype } & \multicolumn{3}{|c|}{ First collection } & \multicolumn{3}{|c|}{ Second collection } \\
\hline & $\begin{array}{c}\text { Number } \\
\text { of different } \\
\text { fruit }\end{array}$ & $\begin{array}{l}\text { Number of } \\
\text { seedlings } \\
\text { analyzed }^{z}\end{array}$ & $\begin{array}{c}\text { Number of } \\
\text { PCR-positive } \\
\text { seedlings }\end{array}$ & $\begin{array}{l}\text { Number of } \\
\text { different } \\
\text { fruit }\end{array}$ & $\begin{array}{l}\text { Number of } \\
\text { seedlings } \\
\text { analyzed }^{z}\end{array}$ & $\begin{array}{l}\text { Number of } \\
\text { PCR-positive } \\
\text { seedlings }\end{array}$ \\
\hline C. macrophylla & 10 & 50 & 0 & 10 & 50 & 0 \\
\hline Vangasay lemon & 10 & 50 & 0 & 10 & 50 & 0 \\
\hline US-802 & 10 & 50 & 0 & 10 & 50 & 0 \\
\hline Cleopatra mandarin & 23 & 69 & 0 & 23 & 79 & 0 \\
\hline Sun Chu Sha & 23 & 69 & $2^{y}$ & 23 & 69 & 0 \\
\hline Sour orange & 10 & 50 & 0 & 10 & 50 & 0 \\
\hline Total & 86 & 338 & 2 & 86 & 348 & 0 \\
\hline
\end{tabular}

${ }^{z}$ Seedlings were selected from fruit exhibiting the strongest PCR signals for $\mathrm{Ca}$. L. asiaticus after peduncle analysis. Leaf midribs and petioles were collected 4 to 5 months (first collection) and 6 to 7 months (second collection) after sowing.

${ }^{y}$ Repeated PCR analysis of seedlings 7, 9, and 15 months after sowing yielded negative PCR results. $\mathrm{PCR}=$ polymerase chain reaction

Table 3. Number of fruit and number of germinated seeds from trees infected with $\mathrm{Ca}$. L. asiaticus located at the USHRL Farm in Fort Pierce.

\begin{tabular}{|c|c|c|c|}
\hline Genotype & Fruit PCR $^{z}$ & Number of fruit & Number of germinated seeds \\
\hline \multirow[t]{2}{*}{ C. macrophylla } & Positive & 29 & 648 \\
\hline & Negative & 19 & 382 \\
\hline \multirow[t]{2}{*}{ Vangasay lemon } & Positive & 22 & 324 \\
\hline & Negative & 27 & 380 \\
\hline \multirow[t]{2}{*}{ US-802 } & Positive & 34 & 1134 \\
\hline & Negative & 22 & 1110 \\
\hline \multirow[t]{2}{*}{ Cleopatra mandarin } & Positive & 38 & 535 \\
\hline & Negative & 62 & 956 \\
\hline \multirow[t]{2}{*}{ Sun Chu Sha } & Positive & 61 & 542 \\
\hline & Negative & 40 & 415 \\
\hline \multirow[t]{2}{*}{ Sour orange } & Positive & 35 & 374 \\
\hline & Negative & 35 & 454 \\
\hline \multirow[t]{2}{*}{ Total } & Positive & 219 & 3557 \\
\hline & Negative & 205 & 3697 \\
\hline
\end{tabular}

${ }^{2}$ PCR detection of $\mathrm{Ca}$. L. asiaticus in fruit was performed on fruit peduncles.

$\mathrm{PCR}=$ polymerase chain reaction . 
seedling growth. Seedling height at 6 months after sowing ranged from $20 \mathrm{~cm}$ in sour orange to $51 \mathrm{~cm}$ in C. macrophylla (Table 5). Presence of the bacterium in source trees or source fruit significantly reduced the height of seedlings from some rootstock genotypes. For C. macrophylla and US-802, this effect was limited to seedlings from PCR-positive fruit $(P<0.002)$. For the cultivars Vangasay lemon, Cleopatra mandarin, and Sun Chu Sha, height of seedlings from both PCR-positive and -negative fruit from infected trees at the Fort Pierce location was reduced when compared with seedlings from noninfected trees from the Whitmore Farm $(P<0.01)$. However, the reverse was true for sour orange seedlings, which were significantly $(P=0.006)$ smaller when derived from seeds from the Whitmore location.

Throughout the experiment, none of the seedlings from any source displayed leaf symptoms characteristic of HLB such as blotchy mottle or yellowing of the veins. Fertilizer removal 5 months after sowing resulted in overall yellowing of leaves of seedlings from all fruit sources without noticeable difference between seedlings from fruit positive or negative for $\mathrm{Ca}$. L. asiaticus. Once fertilization resumed, seedlings quickly regained their regular dark green coloration.

Polymerase chain reaction detection of Ca. L. asiaticus in rootstock seedlings. Of the 3557 seedlings from fruit positive for $\mathrm{Ca}$. L. asiaticus, 338 and 348 were sampled and tested 4 to 5 months and 6 to 7 months, respectively, after sowing. Seedlings were selected from fruit with the strongest PCR signals obtained after peduncle analysis. PCR analysis of petiole and midrib samples of the seedlings detected two of 338 seedlings positive for the bacterium 5 months after sowing (Table 2). However, signal strength of the PCR products was weak (Fig. 1). Both seedlings were of the genotype Sun Chu Sha and originated from seeds of the same fruit. Repeated PCR analysis of both seedlings 7, 9, and 15 months after sowing resulted in negative results and neither plant displayed abnormal growth characteristics or leaf symptoms typical of HLB.

Effect of Ca. L. asiaticus on sweet orange seed quality and seedling growth. PCR analysis of peduncles from HLB-affected fruit confirmed the presence of $\mathrm{Ca}$. asiaticus in all 'Valencia' fruit samples collected from infected trees located at the USHRL Farm in Fort Pierce. A total of 1256 seeds was collected from these fruit compared with 451 seeds collected from trees at the same location that tested negative for the bacterium.

$C a$. L. asiaticus infection significantly $(P=$ 0.0005 ) reduced the average number of seeds in 'Valencia' fruit from 3.8 seeds in noninfected fruit to 2.9 seeds in infected fruit. Similarly, seed weight and percentage of germination were reduced from $213 \mathrm{mg}$ to $172 \mathrm{mg}(P=0.001)$ and from $88 \%$ to $71 \%(P=$ $0.006)$, respectively. The number of seedlings per seed was 1.4 on average and was not significantly affected by the pathogen.
Table 4. Number of seeds per fruit, seed weight, percentage of germination, and number of seedlings per seed for rootstock source trees infected and noninfected with $\mathrm{Ca}$. L. asiaticus.

\begin{tabular}{|c|c|c|c|c|c|c|c|}
\hline Genotype & \multicolumn{2}{|c|}{ Fruit source ${ }^{z}$} & $\mathrm{~N}$ & $\begin{array}{c}\text { Number of } \\
\text { seeds } \\
\text { per fruit }\end{array}$ & $\begin{array}{l}\text { Seed wt } \\
(\mathrm{mg})\end{array}$ & $\begin{array}{c}\text { Seed } \\
\text { germination } \\
(\%)^{y}\end{array}$ & $\begin{array}{c}\text { Number of } \\
\text { seedlings } \\
\text { per seed }^{\mathrm{y}}\end{array}$ \\
\hline \multirow{4}{*}{ C. macrophylla } & PCR-positive & FP & 29 & $30.6 \mathrm{a}$ & $95.9 \mathrm{~b}$ & $66.3 \mathrm{~b}$ & $1.64 \mathrm{a}$ \\
\hline & PCR-negative & FP & 19 & $25.6 \mathrm{a}$ & $119.5 \mathrm{ab}$ & $79.7 \mathrm{ab}$ & $1.67 \mathrm{a}$ \\
\hline & Control & FP & 20 & $32.1 \mathrm{a}$ & $130.1 \mathrm{a}$ & $71.8 \mathrm{ab}$ & $1.65 \mathrm{a}$ \\
\hline & Control & WF & 10 & - & - & $90.8 \mathrm{a}$ & $1.78 \mathrm{a}$ \\
\hline \multirow[t]{3}{*}{ Vangasay lemon } & PCR-positive & FP & 22 & $18.7 \mathrm{a}$ & $85.4 \mathrm{a}$ & $76.7 \mathrm{~b}$ & $1.07 \mathrm{a}$ \\
\hline & PCR-negative & FP & 27 & $18.5 \mathrm{a}$ & $91.2 \mathrm{a}$ & $75.2 \mathrm{~b}$ & $1.11 \mathrm{a}$ \\
\hline & Control & WF & 10 & - & - & $93.7 \mathrm{a}$ & $1.49 \mathrm{a}$ \\
\hline \multirow[t]{4}{*}{ US-802 } & PCR-positive & FP & 34 & $44.9 \mathrm{a}$ & $227.6 \mathrm{a}$ & $94.9 \mathrm{a}$ & $1.35 \mathrm{a}$ \\
\hline & PCR-negative & FP & 22 & $37.0 \mathrm{a}$ & $242.3 \mathrm{a}$ & $96.8 \mathrm{a}$ & $1.44 \mathrm{a}$ \\
\hline & Control & FP & 9 & $42.6 \mathrm{a}$ & $217.8 \mathrm{a}$ & $98.1 \mathrm{a}$ & $1.38 \mathrm{a}$ \\
\hline & Control & WF & 25 & $41.4 \mathrm{a}$ & $265.7 \mathrm{a}$ & $93.5 \mathrm{a}$ & $1.35 \mathrm{a}$ \\
\hline \multirow[t]{3}{*}{ Cleopatra mandarin } & PCR-positive & FP & 38 & $17.5 \mathrm{a}$ & $86.6 \mathrm{a}$ & $80.8 \mathrm{~b}$ & $1.15 \mathrm{a}$ \\
\hline & PCR-negative & FP & 62 & $18.1 \mathrm{a}$ & $85.7 \mathrm{a}$ & $85.0 \mathrm{ab}$ & $1.17 \mathrm{a}$ \\
\hline & Control & WF & 10 & - & - & $93.5 \mathrm{a}$ & $1.25 \mathrm{a}$ \\
\hline \multirow[t]{4}{*}{ Sun Chu Sha } & PCR-positive & FP & 61 & $9.9 \mathrm{a}$ & $98.2 \mathrm{~b}$ & $86.4 \mathrm{~b}$ & $1.49 \mathrm{a}$ \\
\hline & PCR-negative & FP & 40 & $10.8 \mathrm{a}$ & $107.8 \mathrm{a}$ & $95.8 \mathrm{a}$ & $1.46 \mathrm{a}$ \\
\hline & Control & FP & 25 & $9.9 \mathrm{a}$ & $111.6 \mathrm{a}$ & $94.9 \mathrm{a}$ & $1.49 \mathrm{a}$ \\
\hline & Control & WF & 10 & - & - & $97.1 \mathrm{ab}$ & $1.30 \mathrm{a}$ \\
\hline \multirow[t]{3}{*}{ Sour orange } & PCR-positive & FP & 35 & $16.4 \mathrm{~b}$ & $104.1 \mathrm{~b}$ & $61.9 \mathrm{c}$ & $1.10 \mathrm{a}$ \\
\hline & PCR-negative & FP & 35 & $15.4 \mathrm{~b}$ & $110.8 \mathrm{~b}$ & $75.8 \mathrm{~b}$ & $1.12 \mathrm{a}$ \\
\hline & Control & WF & 25 & $37.6 \mathrm{a}$ & $130.7 \mathrm{a}$ & $92.7 \mathrm{a}$ & $1.12 \mathrm{a}$ \\
\hline
\end{tabular}

${ }^{\text {} P C R-p o s i t i v e ~ a n d ~ P C R-n e g a t i v e ~ f r u i t ~ s o u r c e s ~ r e f e r ~ t o ~ f r u i t ~ f r o m ~ i n f e c t e d ~ t r e e s . ~ C o n t r o l ~ f r u i t ~ s o u r c e s ~ r e f e r ~}$ to fruit from noninfected trees. FP = USHRL Farm in Fort Pierce; WF = Whitmore Foundation Farm near Leesburg.

${ }^{y}$ Seed germination and number of seedlings per seed were determined 5 months after sowing.

Data not obtained as a result of logistical constraints are indicated by the dashes. Numbers in each column followed by different letters are significantly different according to Tukey's honestly significant difference test $(P<0.05)$.

$\mathrm{PCR}=$ polymerase chain reaction.

Table 5. Height of rootstock seedlings grown from seeds from rootstock source trees infected and noninfected with $\mathrm{Ca}$. L. asiaticus.

\begin{tabular}{|c|c|c|c|c|}
\hline \multirow{2}{*}{$\begin{array}{l}\text { Genotype } \\
\text { C. macrophylla }\end{array}$} & \multicolumn{2}{|c|}{ Fruit source ${ }^{z}$} & \multirow{2}{*}{$\frac{\mathrm{N}}{271}$} & \multirow{2}{*}{$\frac{\text { Seedling ht }(\mathrm{cm})^{y}}{43.0 \mathrm{~b}}$} \\
\hline & PCR-positive & FP & & \\
\hline & PCR-negative & FP & 104 & $50.7 \mathrm{a}$ \\
\hline & Control & FP & 117 & $50.3 \mathrm{a}$ \\
\hline & Control & WF & 126 & $51.4 \mathrm{a}$ \\
\hline \multirow[t]{3}{*}{ Vangasay lemon } & PCR-positive & FP & 249 & $33.5 \mathrm{~b}$ \\
\hline & PCR-negative & FP & 109 & $37.2 \mathrm{~b}$ \\
\hline & Control & WF & 126 & $46.4 \mathrm{a}$ \\
\hline \multirow[t]{4}{*}{ US-802 } & PCR-positive & FP & 393 & $38.6 \mathrm{~b}$ \\
\hline & PCR-negative & FP & 103 & $42.9 \mathrm{ab}$ \\
\hline & Control & FP & 122 & $46.1 \mathrm{a}$ \\
\hline & Control & WF & 111 & $47.7 \mathrm{a}$ \\
\hline \multirow[t]{3}{*}{ Cleopatra mandarin } & PCR-positive & FP & 408 & $27.9 \mathrm{~b}$ \\
\hline & PCR-negative & FP & 137 & $28.1 \mathrm{~b}$ \\
\hline & Control & WF & 124 & $34.2 \mathrm{a}$ \\
\hline \multirow[t]{4}{*}{ Sun Chu Sha } & PCR-positive & FP & 385 & $26.9 \mathrm{~b}$ \\
\hline & PCR-negative & FP & 135 & $26.0 \mathrm{~b}$ \\
\hline & Control & FP & 132 & $28.6 \mathrm{ab}$ \\
\hline & Control & WF & 126 & $30.2 \mathrm{a}$ \\
\hline \multirow[t]{3}{*}{ Sour orange } & PCR-positive & FP & 288 & $23.8 \mathrm{a}$ \\
\hline & PCR-negative & FP & 123 & $23.1 \mathrm{ab}$ \\
\hline & Control & WF & 123 & $19.6 \mathrm{~b}$ \\
\hline
\end{tabular}

${ }^{2}$ PCR-positive and PCR-negative fruit sources refer to fruit from infected trees. Control fruit sources refer to fruit from noninfected trees. FP = USHRL Farm in Fort Pierce; WF $=$ Whitmore Foundation Farm near Leesburg.

${ }^{y}$ Seedling height was determined 6 months after sowing.

Numbers in each column followed by different letters are significantly different according to Tukey's honestly significant difference test $(P<0.05)$.

$\mathrm{PCR}=$ polymerase chain reaction . 


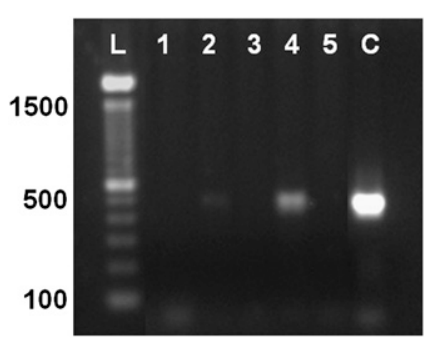

Fig. 1. Polymerase chain reaction (PCR) analysis of Sun Chu Sha seedlings 5 months after sowing. PCR products were separated on a $2 \%$ agarose gel and stained with ethidium bromide. Lanes 1 to 5 contain PCR reactions from five different seedlings derived from the same fruit. PCR products are visible in lanes 2 and 4 . $\mathrm{L}=\mathrm{DNA}$ ladder with fragment sizes in base pairs depicted on the left. $\mathrm{C}=$ positive control from Ca. L. asiaticus-infected citrus plant.

A total of 1313 viable seedlings was produced from seeds, of which 918 originated from fruit positive for the bacterium. Seedlings from fruit infected with $\mathrm{Ca}$. L. asiaticus were significantly $(P=0.004)$ smaller than seedlings from noninfected fruit at 7 weeks of age with an average seedling size of $4.5 \mathrm{~cm}$ and $5.4 \mathrm{~cm}$, respectively.

Polymerase chain reaction detection of Ca. L. asiaticus in sweet orange seedlings. Of more than 900 seedlings derived from fruit positive for $C a$. L. asiaticus, 431 seedlings were analyzed by PCR 7 to 9 weeks after sowing. Analysis of the first pair of leaves emerging above soil level identified three seedlings positive for the bacterium, although PCR signals were weak (Fig. 2). None of the three seedlings displayed any symptoms characteristic for HLB at the time of collection or at any later time point during the experiment. Repeated analysis of midribs and petioles 4 weeks and 9 months after the initial analysis resulted in negative PCR results.

Throughout the experiment, none of the 'Valencia' seedlings developed the blotchy mottling or yellowing of the veins typical of HLB. However, 10 weeks after sowing, leaves from a number of seedlings from both infected and noninfected fruit developed mineral deficiency symptoms-yellowing

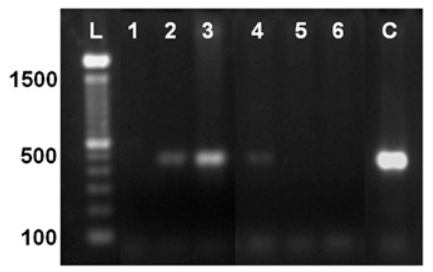

Fig. 2. Polymerase chain reaction (PCR) analysis of sweet orange seedlings 9 weeks after sowing. PCR products were separated on a $2 \%$ agarose gel and stained with ethidium bromide. Lanes 1 to 6 contain PCR reactions from six different seedlings derived from different fruit. PCR products are visible in lanes 2,3 , and $4 . \mathrm{L}=$ DNA ladder with fragment sizes in base pairs depicted on the left. $\mathrm{C}=$ positive control from $C a$. L. asiaticus-infected citrus plant. and bleaching of the leaves - typical of iron deficiency. A total of 27 seedlings (4.8\%) from healthy fruit was affected compared with 107 seedlings $(8.3 \%)$ from fruit positive for $\mathrm{Ca}$. L. asiaticus. Leaf samples were collected from all of the yellow seedlings derived from infected fruit that were large enough for sample collection and subjected to PCR analysis. PCR detection of $\mathrm{Ca}$. L. asiaticus resulted in negative results for all yellow seedlings tested, and deficiency symptoms were remediated on all seedlings within 2 weeks through a soil application of iron chelates and reduced watering.

\section{Discussion}

In a recent study investigating the distribution of $\mathrm{Ca}$. L. asiaticus in different tissues of infected citrus trees (Tatineni et al., 2008), highest concentrations of the bacterium were found in fruit peduncles, evidence of the systemic distribution of the bacterium extending to the reproductive structures of the host plant. In the present study, peduncles of more than half of the 424 fruit collected from infected rootstock seed source trees located at the Fort Pierce Farm were positive for the pathogen. Infection of trees and fruit with $\mathrm{Ca}$. L. asiaticus significantly reduced the seed weight in three of the six rootstock genotypes examined and reduced seed germination in all genotypes with the exception of US-802. Seedlings derived from infected source trees were significantly smaller in five genotypes. However, location of the source trees may have contributed to some of the differences noted. Results from the second experiment performed using infected 'Valencia' sweet orange fruit noticeably affected by HLB confirmed the results obtained for rootstock source trees. Fruit infection significantly reduced the number of seeds per fruit, seed weight and seed germination by $19 \%$ to $24 \%$, and also reduced the height of emerging sweet orange seedlings by $17 \%$. In another study, lower germination rates along with a reduced weight of embryos were also detected in seeds from sweet orange fruit infected with Xylella fastidiosa, a xylemlimited bacterium and causal agent of citrus variegated chlorosis ( $\mathrm{Li}$ et al., 2003). The negative impact of $C a$. L. asiaticus on seed quality and seedling development could be the result of inadequate nourishment of the seeds caused by blockage of the translocation stream from the maternal tissue to the developing embryos. Because phloem transport generally occurs from source areas to sink areas such as developing fruit, phloem blockage may also affect parts of a tree distant from the infection site, leading to the impaired seedling development observed in some rootstock seedlings from infected fruit without detectable pathogen. Blockage of the translocation stream as a result of infection with liberibacters has been suggested by Schneider (1968a). García-Luis et al. (2002) demonstrated that the transport capacity in the phloem of the peduncles does not limit fruit growth in $C$. clementina and that fruit growth is more closely related to the leaf area and current photosynthesis. It is likely that metabolic changes caused by $\mathrm{Ca}$. L. asiaticus, particularly those associated with carbohydrate metabolism and photosynthesis (Albrecht and Bowman, 2008a, 2008b), contribute to the negative effect on fruit and seed development in citrus.

Examination of more than 7000 seedlings produced from seeds from rootstock source trees infected with $C a$. L. asiaticus did not discover any seedlings with disease symptoms associated with HLB. Nearly half of the seedlings (3557) were produced from fruit with peduncles positive for the pathogen. That $C a$. asiaticus infection can cause stunting and yellowing or mottling of the leaves in citrus seedlings younger than 6 months of age was apparent in inoculation experiments performed in our laboratory using fieldcollected infected psyllids (data not shown). The absence of disease symptoms in rootstock seedlings is contradictory to the findings of Tirtawidjaja (1981) who reported stunted, chlorotic seedlings derived from seeds of HLB-affected citrus fruit, of which three had the same mottled appearance as psyllid-inoculated seedlings. Despite the absence of disease symptoms, PCR analysis of 686 individual rootstock seedlings detected two seedlings $(0.3 \%)$ positive for the bacterium. However, PCR products were weak and repeated analysis of the two plants at later time points, including 15 months after sowing, produced negative results.

To confirm these findings, more than 900 'Valencia' sweet orange seedlings produced from infected fruit were analyzed in the second experiment. PCR analyses were conducted soon after germination to ensure detection of a possibly transient presence of the bacterium in the plant tissue. Three of the 431 seedlings tested $(0.7 \%)$ yielded weak PCR products specific for $C a$. L. asiaticus. Repeated PCR analysis at a later time point yielded negative results, corresponding to the results from rootstock seedlings. Similar to rootstock seedlings, none of the 918 seedlings from infected sweet orange fruit developed mottled leaves or other growth abnormalities associated with HLB. However, leaf chlorosis resembling iron-deficiency symptoms developed 10 weeks into the experiment in seedlings from both healthy and HLB-affected fruit but disappeared soon after iron treatment and reduced irrigation. Iron chlorosis is often associated with excessive irrigation (Chapman, 1968) and is not uncommon in young emerging seedlings. Because chlorosis was also observed in seedlings from healthy noninfected fruit, it is likely not associated with HLB. PCR analysis of 91 chlorosis-affected seedlings derived from infected fruit yielded negative results for $C a$. L. asiaticus, thus supporting this view. The higher percentage of chlorosis-affected seedlings produced from infected fruit compared with healthy fruit is most likely associated with the larger number of small seedlings produced from the former, which are more prone to injury 
from wet soil conditions. The leaf chlorosis observed by Tirtawidjaja (1981) may also have been caused by iron deficiency rather than HLB.

Several studies on seed transmission of $C a$. L. asiaticus in citrus reported the detection of a small percentage of seedlings positive for the pathogen using quantitative PCR, but similar to the observations in this study, PCR results were not always confirmed in subsequent testing (Graham et al., 2008). Hartung et al. (2008) did not detect $\mathrm{Ca}$. L. asiaticus in seedlings from HLBaffected fruit applying quantitative PCR according to a method developed by $\mathrm{Li}$ et al. (2006). Analysis of the same plants using different primers identified PCR products specific for the bacterium; however, results were not correlated with the occurrence of disease symptoms. Contrary to the small number of seedlings found positive for $\mathrm{Ca}$. L. asiaticus in the present study, a study conducted with fruit from three sweet orange cultivars infected with the xylem-limited bacterium $X$. fastidiosa identified 59 of 250 seedlings PCR-positive for the pathogen ( $\mathrm{Li}$ et al., 2003). Only 11 of the seedlings developed foliar disease symptoms at the age of 4 months, but symptoms disappeared 1 month later.

Citrus fruit are well-vascularized organs and axial vascular bundles give rise to seed bundles extending along the funiculus into a vascular plexus ending in the chalaza of the developing ovule (Schneider, 1968b). During seed development, the chalaza produces the integuments - inner and outer seedcoat - and the nucellus, thus providing a pathway for the bacterium to enter the seed. Indeed, Tatineni et al. (2008) demonstrated the presence of $\mathrm{Ca}$. L. asiaticus in seedcoats of seeds from infected citrus fruit. The bacterium was not detected in endosperm and embryos, although only a few samples were analyzed in the study. Similarly, the phloem-restricted mulberry dwarf phytoplasma was detected in seedcoats of dwarf-diseased mulberries, but not in the embryo (Jiang et al., 2004), and seed transmission of this pathogen has not been reported. Internal infection of seeds by vascular transmission through peduncles has also been detected in beans inoculated with Xanthomonas campestris pv. phaseoli (Aggour et al., 1989). Planting infected bean seeds did not result in systemic transmission of the bacteria.

Polymerase chain reaction is the main tool for diagnosis of liberibacters and other nonculturable phloem-restricted pathogens. Molecular detection based on DNA sequences is highly sensitive and is not dependent on the viability of the organism. Hence, falsepositive results resulting from crosscontamination such as reported by Walcott et al. (2003) can occur. Provided that PCR products detected during the early development of citrus seedlings are not the result of crosscontamination, detection suggests that bacterial cells or bacterial DNA must somehow be translocated into the tissue of the developing seedling.
In contrast to most angiosperms, citrus exhibits a polyembryonic seed formation in which nonzygotic embryos are initiated directly from the maternal, nucellar cells surrounding the embryo sac, which contains the developing zygotic embryo (Koltunow, 1993). Growth of the nucellar embryos is generally more vigorous and the zygotic embryo often does not form a viable seedling (Frost and Soost, 1968). As the seed matures, the nucellus is isolated from the vascular tissues in the chalaza and the integuments by several layers of epidermal cells, known as the brown layer. The nucellus is thought to function in the absorption and translocation of nutritive material from the vascular tissue of the chalaza to the endosperm and the developing embryos (Schneider, 1968b). Li et al. (2003) concluded that transmission of $X$. fastidiosa into the developing embryo could have occurred along with the ergastic material transported through the nucellus. However, it is unclear how the bacterium could gain entry into the xylem vessels. Despite the possibility that liberibacters and other bacteria can become entrapped within the seedcoat, it seems unlikely that they can enter the vascular system and spread systemically, because no vascular continuity exists between maternal tissue and the developing embryo. Whether some unidentified mechanism of movement could enable the pathogen to access the phloem during seedling development remains to be investigated.

With regard to the nucellar form of embryony in citrus, it seems probable that a few bacterial cells may be translocated from the vascular plexus of the chalaza into the nucellus during the initial stages of seed development where they may become enveloped by the developing nucellar embryo. This would explain why $C a$. L. asiaticus can be detected at a very low frequency in seedlings within the first few months after germination. Alternatively, bacterial transmission may occur externally through contact of the cotyledons or the embryo with the adhering infected seedcoat, as was demonstrated in a study by Kaufman and Leben (1974) on blight-infected soybeans. The fact that $C a$. L. asiaticus was not detected at later time points during seedling development and that no disease symptoms typical for HLB were observed suggests that the pathogen did not exist in a viable form or in susceptible tissues or that environmental conditions were not conducive to the multiplication necessary for virulence.

In conclusion, infection of citrus fruit with HLB negatively affected seed weight, seed germination, and seedling size. Yet, despite the detection of PCR products for $C a$. L. asiaticus in a small percentage of seedlings, none of the seedlings derived from infected fruit developed HLB disease throughout the duration of the experiment, suggesting that the pathogen was not transmitted into the seedling in a way permitting disease development. Four hundred seedlings are currently being kept in our greenhouses for further observations and PCR analysis.

\section{Literature Cited}

Agarwal, V.K. and J.B. Sinclair. 1987. Principles of seed pathology. Vol. 1. CRC Press Inc., Boca Raton, FL.

Aggour, A.R., D.P. Coyne, A.K. Vidaver, and K.M. Eskridge. 1989. Transmission of the common blight pathogen in bean seed. J. Amer. Soc. Hort. Sci. 114:1002-1008.

Albrecht, U. and K.D. Bowman. 2008a. Gene expression in Citrus sinensis (L.) Osbeck following infection with the bacterial pathogen Candidatus Liberibacter asiaticus causing huanglongbing in Florida. Plant Sci. 175:291306.

Albrecht, U. and K.D. Bowman. 2008b. Transcriptional response and carbohydrate metabolism of citrus infected with Candidatus Liberibacter asiaticus, the causal agent of huanglongbing in Florida. In: Proc. 11th Intl. Citrus Congress. ICC, Wuhan, China (in press).

Bové, J.M. 2006. Huanglongbing: A destructive, newly-emerging, century-old disease of citrus. J. Plant Pathol. 88:7-37.

Chapman, H.D. 1968. The mineral nutrition of citrus, p. 127-289. In: Reuter, W., L.D. Batchelor, and H.J. Webber (eds.). The Citrus Industry. Vol. 2. University of California, Oakland, CA.

Darrasse, A., C. Bureau, R. Samson, C.E. Morris, and M.-A. Jacques. 2007. Contamination of bean seeds by Xanthomonas axonopodis pv. phaseoli associated with low bacterial densities in the phyllosphere under field and greenhouse conditions. Eur. J. Plant Pathol. 119:203-215.

Ding, F., G. Wang, G. Yi, J. Zhong, J. Zeng, and B. Zhou. 2005. Infection of wampee and lemon by the citrus huanglongbing pathogen (Candidatus Liberibacter asiaticus) in China. J. Plant Pathol. 87:207-212.

Frost, H.B. and R.K. Soost. 1968. Seed reproduction: Development of gametes and embryos, p. 290-324. In: Reuter, W., L.D. Batchelor, and H.J. Webber (eds.). The Citrus industry. Vol. 2. University of California, Riverside, CA.

García-Luis, A., M.E.M. Oliveira, Y. Bordón, D.L. Siqueira, S. Tominaga, and J.L. Guardiola. 2002. Dry matter accumulation in Citrus fruit is not limited by transport capacity of the pedicel. Ann. Bot. (Lond.) 90:755-764.

Garnier, M., J.M. Bové, C.P.R. Cronje, G.M. Sanders, L. Korsten, and H.F. Le Roux. 2000. Presence of 'Candidatus Liberibacter africanus' in the Western Cape province of South Africa, $p$. 369-372. In: da Graça, J.V., R.F. Lee, and R.K. Yokomi (eds.). Proc. 14th Conf. Intl. Organ. Citrus Virologists. IOCV, Riverside, CA.

Garnier, M., N. Danel, and J.M. Bové. 1984. The greening organism is a gram negative bacterium, p. 115-124. In: Garnsey, S.M., L.W. Timmer, and J.A. Dodds (eds.). Proc. 9th Conf. Intl. Organ. Citrus Virologists. IOCV, Riverside, CA.

Gottwald, T.R., J.V. da Graça, and R.B. Bassanezi. 2007. Citrus huanglongbing: The pathogen and its impact. Online. Plant Health Progress Online publication. DOI: 10.1094/PHP-20070906-01-RV. July 1 2009. <http://www.apsnet. org/online/feature/huanglongbing/>.

Graham, J.H., M.S. Irey, W.O. Dawson, D. Hall, and Y. Duan. 2008. Assessment of transmission of Liberibacter asiaticus from seed to seedlings of 'Pineapple' sweet orange and Carrizo citrange, p. 174. In: Proc. Intl. Res. Conf. on Huanglongbing, Orlando, FL.

Halbert, S.E. 2005. The discovery of huanglongbing in Florida, p. H-3. In: Proc. 2nd Intl. Citrus Canker and Huanglongbing Research Workshop. Florida Citrus Mutual, Orlando, FL. 
Halbert, S.E. and K.L. Manjunath. 2004. Asian citrus psyllids (Sternorrhyncha: Psyllidae) and greening disease of citrus: A literature review and assessment of risk in Florida. Fla. Entomol. $87: 330-353$.

Hartung, J.S., S. Halbert, and R. Shatters. 2008. Can Ca. Liberibacter asiaticus be transmitted through citrus seed? p. 166. In: Proc. Intl. Res. Conf. on Huanglongbing, Orlando, FL.

Jiang, H., W. Wei, T. Saiki, H. Kawakita, K. Watanabe, and M. Sato. 2004. Distribution patterns of mulberry dwarf phytoplasma in reproductive organs, winter buds, and roots of mulberry trees. J. Gen. Plant Pathol. 70:168173.

Kaufman, P.H. and C. Leben. 1974. Soybean bacterial blight: Flower inoculation studies. Phytopathology 64:329-331.

Koltunow, A.M. 1993. Apomixis: Embryo sacs and embryos formed without meiosis or fertilization in ovules. Plant Cell 5:1425-1437.

Li, W., J.S. Hartung, and L. Levy. 2006. Quantitative real-time PCR for detection and identification of Candidatus Liberibacter species associated with citrus Huanglongbing. J. Microbiol. Methods 66:104-115.
Li, W.-B., W.D. Pria, Jr., P.M. Lacava, X. Qin, and J.S. Hartung. 2003. Presence of Xylella fastidiosa in sweet orange fruit and seeds and its transmission to seedlings. Phytopathology 93 953-958.

McClean, A.P.D. and R.E. Schwarz. 1970. Greening or blotchy-mottle disease of citrus. Phytophylactica 2:177-194.

Schneider, H. 1968a. Anatomy of greening-diseased sweet orange shoots. Phytopathology 58:262-266

Schneider, H. 1968b. The anatomy of citrus, p. 185. In: Reuter, W., L.D. Batchelor, and H.J. Webber (eds.). The Citrus industry. Vol. 2. University of California, Berkeley, CA.

Sechler, A., E.L. Schuenzel, P. Cooke, S. Donnua, N. Thaveechai, E. Postnikova, A.L. Stone, W.L. Schneider, V.D. Damsteegt, and N.W. Schaad. 2009. Cultivation of 'Candidatus Liberibacter asiaticus', ' $\mathrm{Ca}$. L. africanus', and ' $\mathrm{Ca}$. L. americanus' associated with Huanglongbing. Phytopathology 99:480-486.

Tatineni, S., U. Shankar Sagaram, S. Gowda, C.J. Robertson, W.O. Dawson, T. Iwanami, and N. Wang. 2008. In planta distribution of ' Candidatus Liberibacter asiaticus' as revealed by polymerase chain reaction (PCR) and real-time PCR. Phytopathology 98:592-599.

Teixeira, D.C., A.J. Ayres, E.W. Kitajima, F.A.O Tanaka, J.L. Danet, S. Jagoueix-Eveillard, C. Saillard, and J.M. Bové. 2005. First report of a Huanglongbing-like disease of citrus in Sao Paulo State, Brazil, and association of a new liberibacter species, 'Candidatus Liberibacter americanus', with the disease. Plant Dis. 89:107.

Teixeira, D.C., N.A. Wulff, E.C. Martins, E.W. Kitajima, R. Bassanezi, A.J. Ayres, S. Eveillard, C. Saillard, and J.M. Bové. 2008. A phytoplasma closely related to the pigeon pea witches'-broom phytoplasma (16Sr IX) is associated with citrus Huanglongbing symptoms in the state of São Paulo, Brazil. Phytopathology 98:977-984.

Tirtawidjaja, S. 1981. Insect, dodder and seed transmissions of citrus vein phloem degeneration (CVPD). Proc. Intl. Soc. Citricult. 1:469471.

Walcott, R.R., R.D. Gitaitis, and A.C. Castro. 2003. Role of blossoms in watermelon seed infestation by Acidovorax avenae subsp. citrulli. Phytopathology 93:528-534. 